\title{
Living on the good soil: relationships between soils, vegetation and human settlement during the late Allerød period in Denmark
}

\author{
Morten Fischer Mortensen • Peter Steen Henriksen • \\ Ole Bennike
}

Received: 23 August 2013/Accepted: 12 January 2014

(C) The Author(s) 2014. This article is published with open access at Springerlink.com

\begin{abstract}
The immigration of woody plants, especially Betula (tree birch), is examined in relation to geomorphological regions in a compilation of Late-glacial plant macrofossil records from Denmark. The immigration of trees led to a large ecological transformation of the landscape and had a major effect on the flora and fauna available to Palaeolithic people. We show that soil type was a controlling factor in the development of vegetation during the Allerød and Younger Dryas periods. Following the first immigration of trees during the Allerød period, woods became established in the eastern part of Denmark, where ice advances from the Baltic had deposited calcareous and clayey sediments. The western and northern parts of Denmark that are characterised by more sandy and noncalcareous sediments remained treeless throughout the whole Late-glacial period. Finds from the Bromme Culture are concentrated in the region which was wooded, suggesting that the regional variable environment allowed local adaptations using the diverse resources available.
\end{abstract}

Keywords Late-glacial - Macrofossils · Bromme Culture $\cdot$ Palaeoecology $\cdot$ Vegetational development

Electronic supplementary material The online version of this article (doi:10.1007/s00334-014-0433-7) contains supplementary material, which is available to authorized users.

M. F. Mortensen $(\varangle)$ · P. S. Henriksen

Environmental Archaeology and Materials Science, The

National Museum of Denmark, Ny Vestergade 11,

1471 Copenhagen K, Denmark

e-mail: morten.fischer.mortensen@natmus.dk

O. Bennike

Geological Survey of Denmark and Greenland,

Øster Voldgade 10, 1350 Copenhagen K, Denmark

\section{Introduction}

The immigration of trees led to one of the largest landscape transformations of the Late-glacial period in previously glaciated or periglacial regions, such as Denmark. Open tundra turned to woodland and instigated major ecological changes in the composition of both flora and fauna (AarisSørensen 2009; Mortensen et al. 2011). The vegetation of light, open, non-wooded areas with unstable soils often consists of stress-tolerant taxa (Petersen and Vestergaard 2006). In contrast, more competitive taxa are favoured by the development of woods where erosion is reduced, soils develop more rapidly and less light is available (Packham et al. 1996). Major changes in the faunal composition are most clearly seen in the large herbivores where the open tundra landscape was dominated by large flocks mainly of Rangifer tarandus (reindeer), which were replaced by the more solitary Alces alces (elk) and Megaloceros giganteus (giant deer) in the Late-glacial woods (Aaris-Sørensen and Liljengren 2004; Aaris-Sørensen 2009). The presence or absence of trees and the development of woods is therefore of great importance when considering the Late-glacial flora and fauna. Similarly important when considering the archaeological material is the distinction between open land and woodland, because the local environmental conditions would have been crucial for hunting strategies, occupation site locations, tool requirements and the general subsistence economy (Bos et al. 2012; Mortensen et al. in press).

Although pollen analyses have been used successfully to determine tree lines (Hicks 2001; Seppä and Hicks 2006) and vegetation patterns (Theuerkauf and Joosten 2009, 2012), dating the immigration of trees and the development of woods is not without difficulties (Van Dinter and Birks 1996; Birks 2003; Seppä et al. 2004). Betula pubescens 
(tree birch) was the dominant tree taxon during the Lateglacial period in Denmark but the separation of tree birch pollen from that of $B$. nana (dwarf birch) is problematic (Birks 1968; Usinger 1977; Andersen 1980). In addition, local pollen production is limited in Arctic environments, and the contribution of pollen transported a long distance can be disproportionately high, which can lead to misleading results (see Birks and Birks 2000). A classic example of this effect can be seen in the immigration of birch reconstructed from pollen analysis, as opposed to plant macrofossil analysis. A significant time difference may be seen in comparative studies where pollen analyses indicate the presence of tree birch much earlier than that indicated by the presence of tree birch macrofossils (Birks 1993, 2003). Additionally, analyses of plant macrofossils can give a greater diversity and a more detailed reconstruction of vegetational development than from pollen analysis alone (Birks 1993, 2001; Birks and Birks 2000; Bos et al. 2006; Hofstetter et al. 2006; Mortensen et al. 2011).

The Late-glacial vegetational development of Denmark was already known by the mid 20th century from numerous studies conducted during the pioneer phase of pollen analysis (Iversen 1942, 1954; Krog 1954). These indicated that tree birch had already immigrated to the region during the Bølling warming and formed part of the so-called park tundra (Iversen 1954). Woods were thought to have been present by the beginning of the Allerød period and Denmark was believed to have been covered by woods by the middle of that period. Especially the southern part of Denmark was thought to have had a relatively dense birch woodland with Populus (poplar), Juniperus (juniper), Sorbus (rowan) and Pinus (pine), with the latter particularly common towards the east. A more open woodland would have existed towards the north (Iversen 1942, 1954). This general picture of the Late-glacial woodland in Denmark has largely prevailed (Noe-Nygaard et al. 2006).

More recent studies, however, have led to a more detailed picture of the Late-glacial landscape of Denmark. Kolstrup (2007) demonstrated cover sand activity in western Denmark during the Allerød, which suggests that the woods, at least in western Denmark, must have had areas of open, sparsely vegetated ground that could have provided the source material. This interpretation is supported by several detailed plant macrofossil analyses from Bølling Sø, none of which have found tree birch during the Lateglacial period (Brandt 1954; Stockmarr 1975; Usinger 1985; Bennike et al. 2004b). Nor have combined analyses of pollen and plant macrofossils from two localities in southern Denmark been able to show such an early immigration of tree birch; both show that it did not become established until the middle of the Allerød period (Mortensen et al. 2011; Mortensen et al. in press).
The reasons for the late arrival of tree birch are probably related to the lack of suitable soils together with very dry conditions, known to be a limiting factor for birch immigration (Mortensen et al. 2011). Limiting factors to vegetational development are especially relevant when applying pollen and plant macrofossil analyses to palaeotemperature reconstructions and plant responses to climatic change (Birks and Birks 2006; Aarnes et al. 2012).

The aims of this paper are:

- To date the arrival of tree birch in Denmark using ${ }^{14} \mathrm{C}$ dating of plant macrofossils and megafossils together with macrofossil analysis of dated sediment sequences.

- To examine whether, and by how much, soil types have influenced the immigration and establishment of tree birch during the Allerød. We review all Late-glacial plant macrofossil analyses from Denmark and assess the data in relation to regional geomorphological regions.

- To examine whether there is a relationship between finds from the Bromme Culture and woodland development during the Allerød. The Bromme Culture dates to the second half of the Allerød when woodland development was most advanced and the archaeological finds are concentrated in a relatively limited region of southern Scandinavia.

\section{Site locations}

The region considered is shown in Fig. 1 with the approximate positions of land, sea and lakes during the Late-glacial period (Fischer et al. 2013a). Danish soil types are generally defined by three geomorphological regions formed by the Scandinavian ice sheet advances and retreats during the Saalian and Weichselian glaciations (Houmark-Nielsen and Kjær 2003). Region A covers western Jylland (Jutland) and is characterised by leached Saalian till and sandy Weichselian glacio-fluvial deposits. Region B is characterised by sandy and calcium-poor sediments deposited during the last glacial maximum around 22,000 cal. B.P. Region $\mathrm{C}$ is characterised by clayey and calcareous sediments deposited by glaciers that advanced through the Baltic around 19,000 cal. B.P. (Houmark-Nielsen and Kjær 2003; Münier 2009). Bornholm, farthest to the east, is characterised by bedrock with some sediments from the last Baltic ice advance. In this paper, Bornholm is considered part of Region C. The sites shown in Fig. 1 were found through a review of the literature and hitherto unpublished data from the archives at the Danish National Museum and the Geological Survey of Denmark and Greenland. The objective was to include as many sites as possible. Many of the data used were acquired in the late 19th and early 20th centuries 
Fig. 1 Map of Denmark showing the approximate positions of land, sea, lakes and ice during the Late-glacial period. Site numbers refer to ESM 2; sites discussed in the text are numbered in red. Region A is predominantly leached Saalian till and Weichselian glacio-fluvial deposits. Region $B$ is predominantly sandy noncalcareous sediments deposited during the last glacial maximum c. 22,000 cal. B.P. Region $C$ is predominantly clayey and calcareous sediments deposited by the late Baltic Ice Advance c. 19,000 cal. в.P.

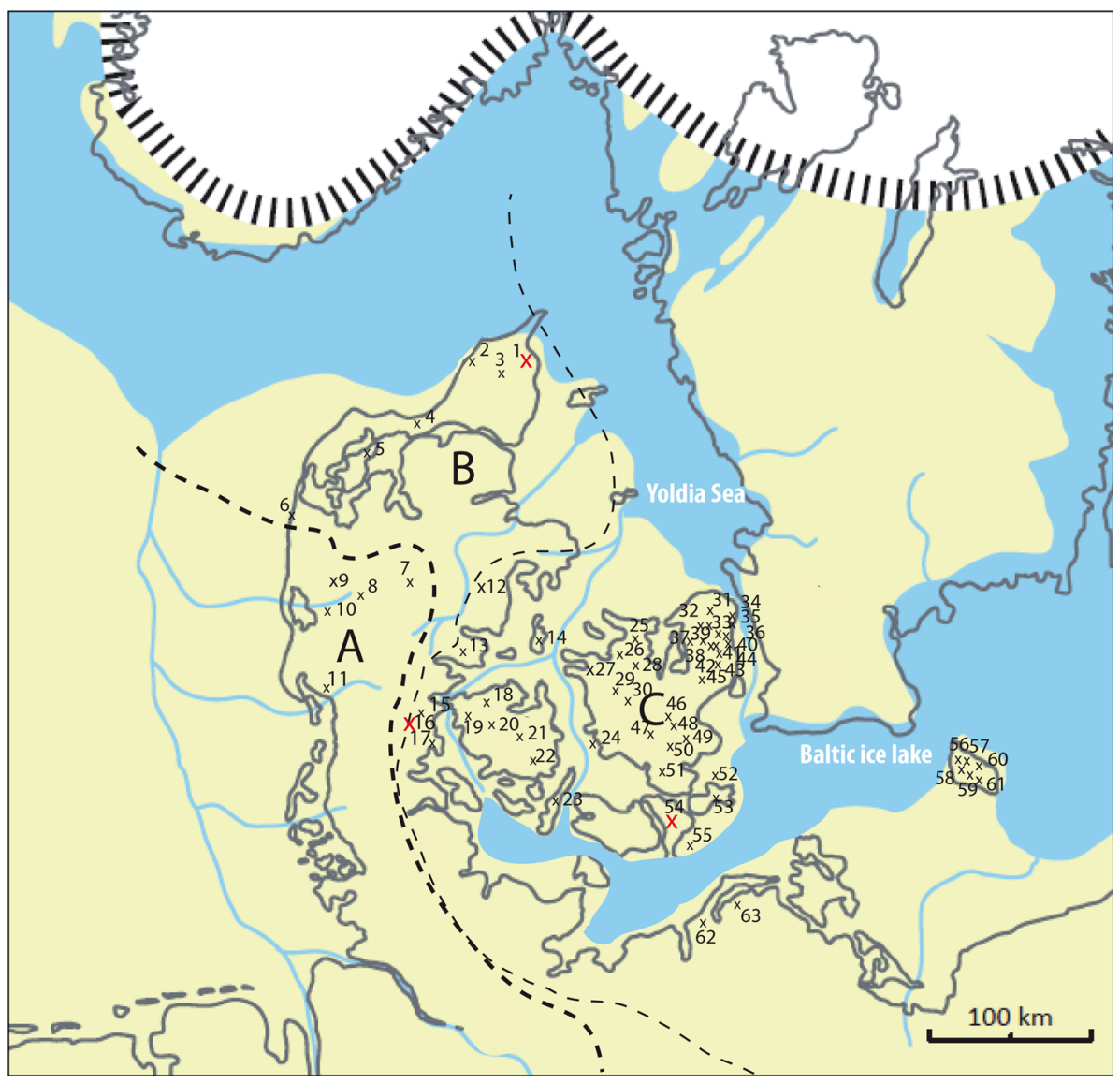

Table 1 Ages of the first arrival of tree birch in Late-glacial sediments in Denmark

\begin{tabular}{lllllll}
\hline Loc. no. & Locality & Lab. no. & Age, ${ }^{14}$ C (в.P.) & Age, $2 \sigma$ range (cal. B.P.) & Material & Reference \\
\hline 14 & Martin Holms Mose & K-3079 & $11,770 \pm 100$ & $13,828-13,392^{\mathrm{a}}$ & Wood & This work \\
16 & Slotseng & & & 13,500 & A-D curve & Mortensen et al. (2011) $^{\text {( }}$ \\
27 & Staals $\varnothing$ & & 13,700 & A-D curve & This work \\
53 & Tøvelse & AAR-3555 & $11,750 \pm 70$ & $13,415-13,776^{\mathrm{a}}$ & Bark, twigs & Noe-Nygaard and Heiberg (2001) \\
54 & Hassel $\varnothing$ & & & 13,600 & A-D curve & Mortensen et al. (in press) \\
\hline
\end{tabular}

${ }^{\mathrm{a}}$ Mean $=13,600$

b Age-depth curve

when geologists and other naturalists routinely visited open pits such as clay pits to describe plant macrofossils from Late-glacial and early Holocene sediments (Nathorst 1871; Hartz and Milthers 1901). Samples were collected from exposed profiles and were therefore large. Modern studies are usually based on much smaller samples collected from sediment cores, but with higher resolution and better chronology. In Denmark, Allerød sediments usually consist of gyttja or peat whereas Younger Dryas sediments usually consist of mineral-rich sediments, allowing a relatively reliable separation. This is particularly the case in southeastern Denmark, but also in the west and north the two periods can be identified on the basis of their organic content
(Iversen 1947). This allows the results of older studies to be used even in the absence of ${ }^{14} \mathrm{C}$ dates or pollen stratigraphies.

\section{Methods}

Dating the immigration of tree birch

The first appearance of tree birch macrofossils from dated Late-glacial sequences or from ${ }^{14} \mathrm{C}$ dated megafossils is presented in Table 1 . The table only includes early appearance of tree birch, whereas younger dates are not included. Dates were 
calibrated and age-depth models constructed with OxCal 4.2 (Bronk Ramsey 2009) using the IntCal09 radiocarbon calibration curve (Reimer et al. 2009). Plant macrofossil diagrams from Slotseng (Mortensen et al. 2011), Hasselø (Mortensen et al. in press) and Lendum (unpublished data) are used as examples of the local vegetational development in the Danish region (Fig. 2). The three sites were selected because they represent different parts of the study area. All three sites have been analysed for pollen and macrofossils and are well dated. The full data set from Lendum will be published elsewhere, but the ${ }^{14} \mathrm{C}$ age determinations and the age/depth model can be found in ESM 1.

Tree birch distribution

Macrofossil data have been compiled on woody plants from a total of 61 sites in Denmark along with two sites from northern Germany (Fig. 1, ESM 2, 3). Many of the sites included have relatively low biostratigraphic resolution and are therefore categorised as either Allerød or Younger Dryas. The presence or absence of tree birch macrofossils at all Allerød sites is shown (Fig. 3a). Similarly, macrofossils of Populus, and Empetrum (crowberry) are shown for the Allerød and those of Empetrum and Dryas (mountain avens) are shown for the Younger Dryas (Fig. 3b). As shown in ESM 2, B. pendula (silver birch) was recorded at a few of the sites analysed in the early years, but as macrofossils of $B$. pubescens (downy birch) can be very variable, these have probably been misidentified. Tree birch macrofossils are found in Younger Dryas sediments at a few sites (ESM 2). These are assumed to be redeposited or they may belong to the fairly long transition zone during which Allerød vegetation was replaced by Younger Dryas vegetation.

All sites with Allerød sediments from regions A and B are included regardless of the presence of tree birch macrofossils. There are comparatively few sites from these regions but most are well dated (ESM 2). A few sites were omitted from Region $\mathrm{C}$ because we were uncertain if the samples belong to the Allerød.

\section{Archaeological data}

'Large tanged points' are characteristic of the Bromme Culture and information on the finds was retrieved from Eriksen (1999), Pedersen (2009) and from the online databases www.lateglacial.org and www.dkconline.dk (accessed 20 June 2013). Relatively few Bromme occupation sites are known and their distinction from stray finds has been noted. Information on finds from northern Germany and Sweden is from Terberger (2006). Even though the databases and the literature are likely to use different criteria for the categorisation of material, the overall
Fig. 2 Macrofossil diagrams from Lendum, northern Jutland (Site 1, Region B), Slotseng, southwest Denmark (Site 16, Region C) and Hassel $\varnothing$, southeast Denmark (Site 54, Region C). The appearance of tree birch at each site is highlighted in red; the numbers show concentration of macrofossils per $100 \mathrm{ml}$ sediment

picture of find sites is as shown in Fig. 4. The Bromme Culture is mostly known from lithic artefacts and organic material (bones and charcoal) is only known from three Danish sites. ${ }^{14} \mathrm{C}$ dating has yielded late Allerød ages (Fischer et al. 2013a).

\section{Results and discussion}

When did tree birch immigrate into Denmark?

It has been argued that tree birch immigrated to the Danish region during the Bølling period (14,700-14,100 cal. B.P.) (Iversen 1954; Kolstrup 1982; Paus 1995; Noe-Nygaard et al. 2006) but no tree macrofossils have been found at any of the few known sites with Bølling age sediments (Mortensen et al. 2011). The data rather suggest that tree birch arrived around 1,000 years later at c. 13,600 cal. B.P., in the middle of the Allerød period. This delay in immigration was probably not due to temperature limitations, as the Bølling period is known to have been favourable for the establishment of tree birch in the Danish region (Coope et al. 1998; Renssen and Isarin 2001). It has been suggested that soil conditions and aridity could have prevented immigration until the middle of the Allerød (Mortensen et al. 2011) and an increase in precipitation has been linked to the spread of tree birch and woodland development in northern Germany during this time period (Usinger 1998; De Klerk 2008; De Klerk et al. 2001). Although it is problematic to use negative evidence to suggest the absence of tree birch from the Danish region until c. 13,600 cal. B.P., the lack of macrofossils of tree birch from sedimentary sequences before this date cannot be ignored and we propose that the available data indicate that tree birch did not arrive earlier than the middle of the Allerød period. In northwestern Skåne, southern Sweden, three macrofossil diagrams may indicate that tree birch already immigrated there prior to or during the Bølling period (Jönsson 1988). However, the chronologies of these records are based on dating of bulk sediment samples with low organic content and aquatic mosses, and the dating could therefore be ambiguous.

When do individual trees form woods?

The immigration of the first individual trees to the Danish region predated the first development of woods, but it is difficult to establish the transition from trees to woodland 

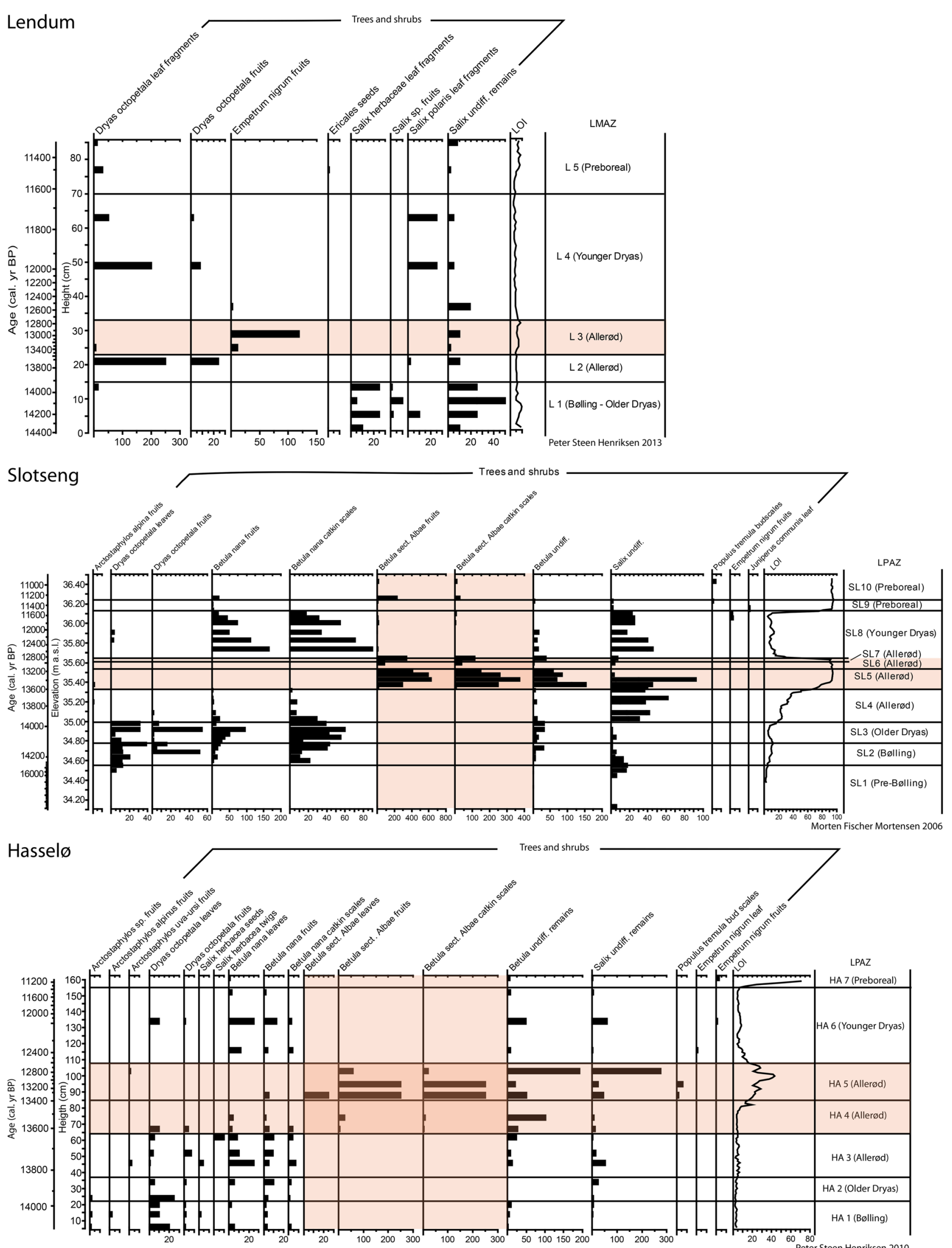
from palaeoecological data, as it occurred gradually and especially because tree birch can also grow as a large bush. Sporadic macrofossils of tree birch were found at Hassel $\varnothing$ in southeast Denmark between c. 13,600 and 13,400 cal. B.P. prior to a more distinct increase (Fig. 2). It occurs at the same time as a major increase is seen in organic content, which is most likely associated with more widespread woodland cover. The grasses and herbs that dominate open ground taxa accumulate a high proportion of their biomass in the root system, in contrast to those of wooded areas which accumulate a greater proportion of biomass on the ground surface through the annual leaf fall (Packham et al. 1996). The establishment of woods around lake basins would therefore be expected to result in an increase in the input of allochthonous organic material into the lake. At the same time a decrease in the input of inorganic material due to a reduction in erosion can be expected. The loss-onignition (LOI) data from Hasselø most probably reflects this development (Fig. 2). Additionally, a gradual reduction and disappearance of light demanding taxa such as Dryas, Salix herbacea and B. nana in favour of more shade tolerant ones such as Populus is seen after c. 13,400 cal. B.P. In Slotseng a similar increase in organic content is seen around 13,500 cal. B.P. when the first tree birch is recorded (Fig. 2). However, in Slotseng some of the light demanding taxa such as $B$. nana do not disappear but continue to be present in relatively large quantities throughout this "woodland period". This indicates that the woodland around Slotseng had a more open character and never became quite as dense as at Hasselø. Trees did not reach Lendum in northern Jutland (Region B) and LOI values remain low throughout the Late-glacial (Fig. 2).

Where does the woodland migrate to?

This paper examines Late-glacial plant macrofossil data from a total of 63 sites covering the Allerød and the Younger Dryas time periods. Macrofossils of tree birch were found at 26 out of the 31 Allerød sites in Region C, while no tree birch macrofossils were found at the seven Allerød sites in Regions A and B. ${ }^{14} \mathrm{C}$ dates from five of the sites (1, 2, 3, 6 and 7) in Region A and B place the sediments in the second half of the Allerød (ESM 2), suggesting that the absence of tree birch is not due to the sediment being older than 13,600 cal. B.P., but rather that there is an actual absence of tree birch macrofossils. The consistent age around 13,600 cal. B.P. in Region C suggests that this pattern is probably not due to dispersal rates. Neither is temperature thought to have been a decisive factor. Even though the average temperatures in northern Jutland may have approached the thresholds for the dispersal of tree birch, there are no indications of a strong east-west temperature gradient across Denmark (Coope et al. 1998).

However, there appears to be a strong relationship between geomorphological regions and the spread of tree birch even though only limited data are available for Regions A and B compared with Region C (Fig. 3a). The

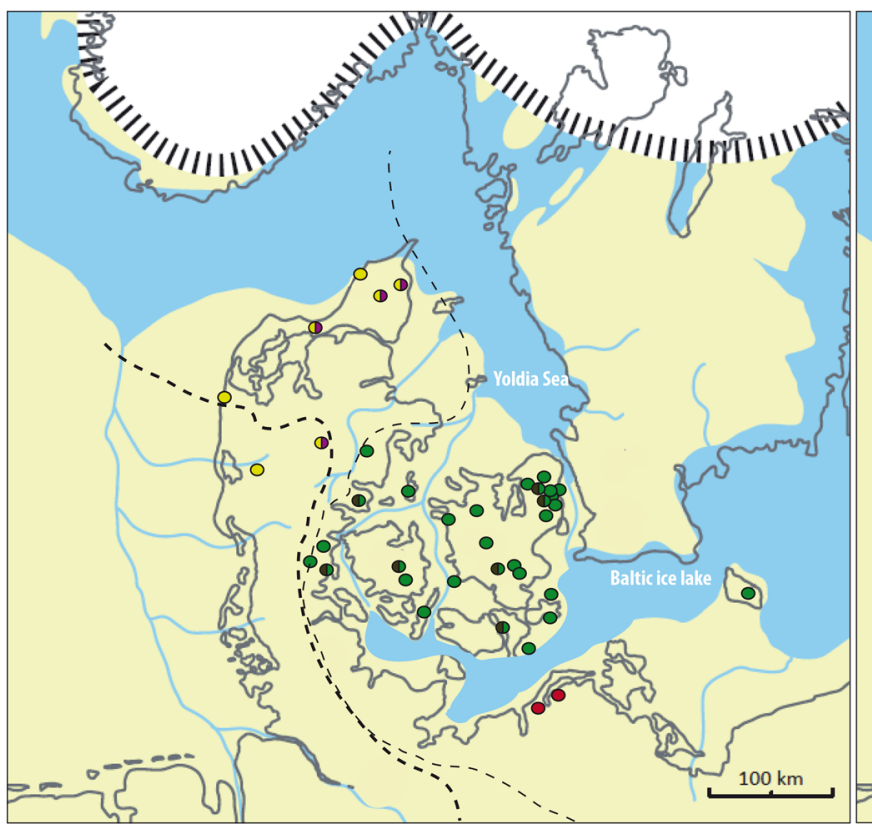

Fig. 3 Map showing the position of macrofossils of selected plant taxa. a Late Allerød, green samples with tree birch; brown samples with Populus tremula; yellow samples without tree birch; purple

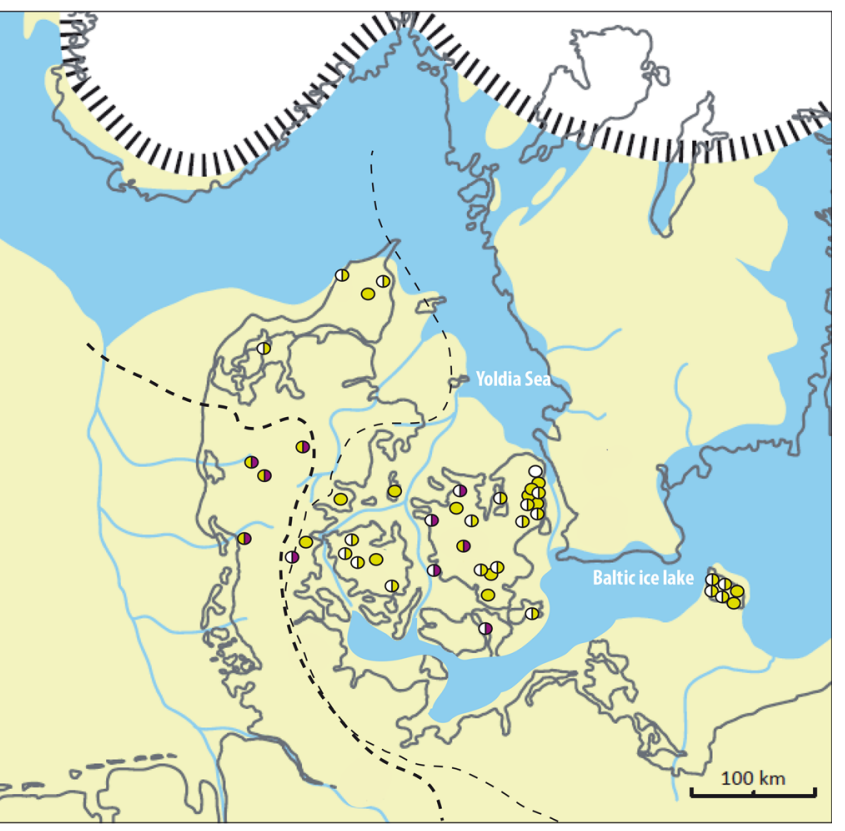

samples with E. nigrum; red samples with Pinus sylvestris. b Younger Dryas, yellow: samples without tree birch; purple samples with E. nigrum; white samples with Dryas octopetala 


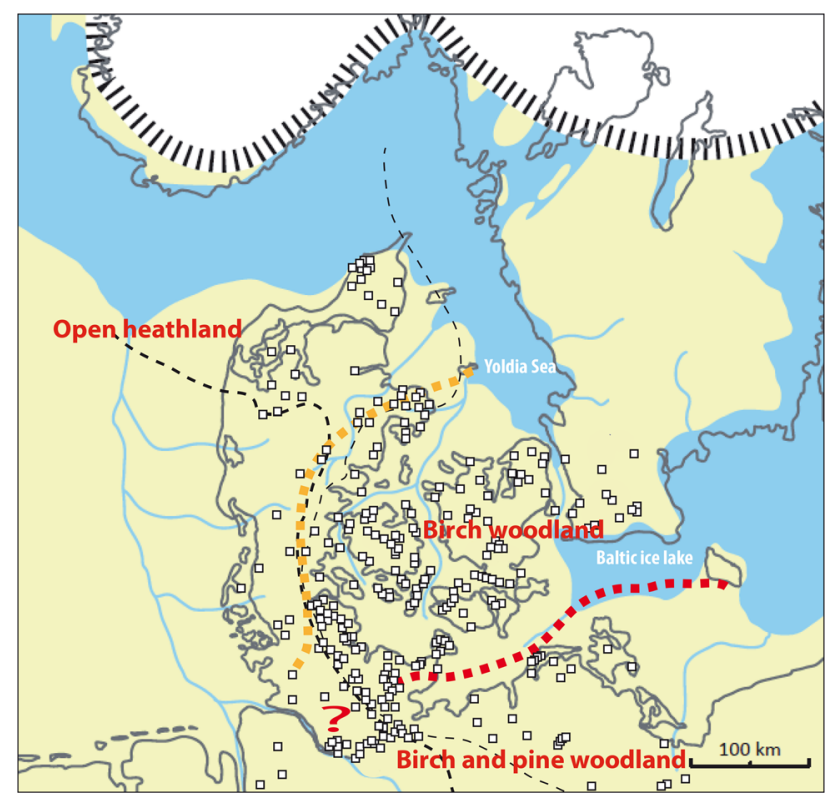

Fig. 4 Map of the predominant landscape types during the late Allerød, based on plant macrofossil finds (Fig. 3a) overlain with positions of Bromme Culture finds (white squares)

simplest explanation is that the geological background of the various regions led to different soils on which the Lateglacial vegetation could develop, as was also found in The Netherlands and in northern Germany (Hoek 1997; Theuerkauf and Joosten 2009). The geological background effects vegetational development in two significant ways. Firstly, the geology influences how rapidly the soils develop and thus how rapidly the local plant succession can take place (Mortensen et al. 2011) and secondly, and perhaps more importantly, the geology influences the field capacity, which determines how quickly plants are affected by water stress (Aslyng 1976). The field capacity of Regions A and B is generally low due to the sandy sediments, and plants in these regions would often be water stressed. This is not the case in Region $\mathrm{C}$ where the sediments have a higher field capacity. We suggest that Allerød summers were relatively dry and that the low field capacity prevented the spread of tree birch to Regions A and B since B. pubescens is sensitive to summer drought (Nikolov and Helmisaari 1992).

A marked difference in vegetation between the regions is seen in the Younger Dryas (Fig. 3b). In contrast to the Allerød where Region $\mathrm{C}$ differs from $\mathrm{A}$ and $\mathrm{B}$, during the Younger Dryas Region A differs from B and C. Dryas favours calcareous soils and is widespread in Regions B and $\mathrm{C}$ but not recorded in the predominantly glaciofluvial sediments and Saalian till of Region A. In Region A, Empetrum nigrum thrives due to its preference for sandy, leached soils (Petersen and Vestergaard 2006). This close relationship between soil type and vegetation continues throughout the Holocene and the large variations seen in both wild and cultivated plants between the different regions can be ascribed to the different geologies of the regions (Odgaard 1994; Odgaard and Nielsen 2009; Frederiksen et al. 2009). Even at the present day the distributions of several plants are tied to the regional geology, for example species such as Cuscuta europaea (greater dodder) and Arctium nemorosum (wood burdock) are mainly restricted to Region C, while species such as E. nigrum (crowberry) and Myrica gale (bog myrtle) mostly grow in Regions A and B (Mossberg and Stenberg 2003; www. fugleognatur.dk accessed d.26 June 2013).

These major vegetational differences between geological regions would be difficult to reconstruct from pollen analyses alone (Theuerkauf and Joosten 2009) and this study underlines the importance of studying plant macrofossils when attempting to obtain a representative picture of the Late-glacial plant succession. It also shows that the underlying geology was an important factor during both warm and cold periods and that even within a relatively limited geographical area, vegetational development can vary due to differences in soil type. This is particularly important when using pollen and plant macrofossil data as proxies for past temperatures (Renssen and Isarin 2001; Seppä et al. 2004; Aarnes et al. 2012). Temperature is obviously not always the limiting factor for the resulting vegetational composition.

\section{The late Allerød landscape}

The compiled plant macrofossil data give a more refined image of the Late-glacial vegetation in Denmark than previously seen, and they show that during the Allerød there was a strong ecological gradient (ecotone) between sandy regions (A and B) and more clay-rich regions (C). The vegetation in the sandy regions consisted of open heathlands with light-demanding plants and was probably dominated by dwarf shrub taxa such as E. nigrum and B. nana (Fig. 3a, ESM 2). On the other hand, the landscapes of Region $\mathrm{C}$ were wooded and dominated by tree birch (probably B. pubescens) but also with Populus and Juniperus (Fig. 3a, ESM 2) and probably also Sorbus (Mortensen et al. in press). This woodland was most probably denser towards the east relative to the north and west. Plant macrofossils of Pinus have not been recorded from Late-glacial sediments in Denmark (Mortensen et al. 2011) but Pinus megafossils have been found immediately to the south in northern Germany, dating to the end of the Allerød (ESM 2). The distance between Denmark and northern Germany is only around $50 \mathrm{~km}$ and it is interesting to note that no Pinus macrofossils have been found at Danish sites. It is possible that Pinus did not grow close to any of the investigated sites. It is also possible that 
macrofossils of Pinus have been overlooked, but both explanations seem unlikely given the number of sites which have been analysed from the region. An alternative explanation could be that Pinus immigrated relatively late to northern Germany and that the low lying region between Denmark and northern Germany, which during the Allerød was occupied by the Baltic Ice Lake (Bennike and Jensen 1998, 2013; Bennike et al. 2004a), acted as a barrier to the dispersal of Pinus (Mortensen et al. in press).

The climate cooling at the end of the Allerød had a marked effect on the vegetational succession and the development of the Late-glacial woodland. The NGRIP ice core data show that the change from the warm GI-1a period to the colder GS-1 period occurred at $12,896 \pm 138 \mathrm{~b} 2 \mathrm{k}$ (12,846 cal. в.P.) (Rasmussen et al. 2006). Pollen reconstructions indicate that the vegetation responded with very little delay to this cooling (Hoek 2001), but there could still have been a significant amount of time between the GI-1a/ GS-1 transition in the Greenland ice cores and the Allerød/ Younger Dryas vegetational transition in Denmark. The Allerød/Younger Dryas transition is dated from numerous terrestrial sites. One of the best dated sites is Kråkenes in western Norway, where the transition is dated to $12,711 \pm 52$ cal. B.P. (Lohne et al. 2013). In a number of annually layered lake sequences from Germany the transition is dated to between $12,679 \pm 30$ and $12,606 \pm 40$ varve years B.P. (Zolitschka et al. 2000; Brauer et al. 2001; Neugebauer et al. 2012). These ages generally agree well with the pollen and plant macrofossil studies from Hasselø, where the first response to a cooler climate, seen as a gradual opening of the woodland, is dated to around $12,730 \pm 145$ cal. в.P. The Allerød environment in southeastern Denmark continued until c. 12,575 \pm 74 cal. B.P. before the ecosystem collapsed and was replaced by Younger Dryas vegetation (Mortensen et al. in press). In this region, this extended transition from Allerød to Younger Dryas vegetation is supported by two unpublished radiocarbon dates of tree birch megafossils from Birkerød which were also dated to after the GI-1a/GS-1 transition (K-6151 10,490 $\pm 155: 12,688-11,826$ cal. B.P. $2 \sigma$ and $\mathrm{K}-620210,970 \pm 165: 13,185-12,586$ cal. в.P. $2 \sigma)$.

The extent of the Bromme Culture in southern Scandinavia

There are only a few available radiocarbon dates for the Bromme Culture in Denmark (Fischer et al. 2013a) and they fall at the transition between the Allerød and the Younger Dryas (Mortensen et al. in press). A slightly older find of a reindeer rib with distinct cut marks from Nørre Lyngby has been dated to $11,570 \pm 110 \mathrm{cal}$. B.P. This most likely belongs to the Bromme Culture although it is an isolated stray find and lacks any cultural context (Fischer et al. 2013b). The Bromme Culture has traditionally been described as a woodland culture and is almost exclusively a southern Scandinavian phenomenon with a distinct concentration in eastern Denmark (Jensen 2001; Pedersen 2009). It is unlikely that this spatial distribution reflects a concentration of research, as the whole of Denmark has been intensively surveyed (Petersen 2009). The Bromme Culture arose relatively late in the Allerød and its restricted geographical range has been the subject of continued discussions regarding its origin (Eriksen 1999; Riede 2008; Pedersen 2009; Sørensen 2010). Different non-cultural causes have been proposed including the climatic and environmental changes that occurred during the Allerød (Mathiassen 1947; Fischer and Mortensen 1977; Johansson 2003; Pedersen and Petersen 2006). Lately it has been suggested that the widespread ash fall from the Laacher See volcano in central Germany at 12,932 cal. B.P. caused a cultural split in the various groups of the Federmesser Culture. This cultural isolation may have caused a technological simplification and the loss of the bow and arrow technology in the Danish and northern German regions and led to the rise of the Bromme Culture (Riede 2008; Riede and Edinborough 2012). Sørensen (2010) suggests that the appearance of this culture and its technological simplifications was not due to cultural isolation but rather because there were rich and easily accessible flint resources available within its geographical area. Considering the archaeological material together with the landscape reconstruction presented here, a further explanation can be suggested based on the Bromme Culture's subsistence potential available within a relatively limited area. It can be seen in Fig. 4 that the Bromme Culture had a strong connection to wooded landscapes. Its main distribution is centred between several different ecosystems which would have provided numerous available subsistence strategies. It is well known that the zones between ecosystems have a particularly high biodiversity (Petersen and Vestergaard 2006) with a wide variety of resources which can be exploited throughout the seasons and within a relatively limited geographical area (Fig. 4). It would have been possible to hunt reindeer in the treeless landscapes of west and north Jutland (Aaris-Sørensen 2009; Fischer et al. 2013b) while elk, giant deer and Ursus arctos (brown bear) would have been potential prey in wooded regions in eastern Denmark. Northern Germany with its birch-pine woods would most likely also have provided alternative exploitable resources. Although the evidence is fragmentary, the coastal zones of the Yoldia Sea and Baltic Ice Lake may have supplied a rich variety of resources for the Palaeolithic people, for example, a wide variety of birds for hunting and egg/chick collection along with resources from the marine environment (Fischer et al. 2013b). Fishing was practised far back into the Palaeolithic (Gramsch et al. 
2013) and the numerous wetland areas formed by melting of stagnant ice provided potential freshwater areas for catching fish such as Esox lucius (pike) and Perca fluviatilis (perch), whose sticky eggs are quickly spread by waterfowl. Lastly there were also the vegetational resources which were not only used for food (Tyldesley and Bahn 1983; Aura et al. 2005; Revedin et al. 2010) but also provided for tool making and material culture (Riede 2012; Nadel et al. 2013). It is therefore conceivable that the appearance of the Bromme Culture and its distribution should be seen in relation to the immigration of tree birch and the development of birch woods and the multifaceted landscape which emerged in the last half of the Allerød period. This was a variable landscape which supplied a diverse and comprehensive subsistence economy for its inhabitants.

\section{Conclusions}

This study expands on the classical interpretation of Lateglacial woodland development in Denmark, and the main points can be summarised thus:

- The immigration of tree birch around 13,600 cal. B.P. was much later than previously thought.

- The distribution of woodland was restricted to areas where ice advances from the Baltic had deposited calcareous, clayey sediments.

- The vegetational succession was much more complex than previously thought, and soil types were the most important limiting factor during both warm and cold Late-glacial periods.

- Although climatic changes obviously account for the major vegetational changes during the Late-glacial, within the Allerød and Younger Dryas periods themselves, it was the difference in soil development and field capacity which was the most important factor in the observed variation between the three geomorphological regions.

- The strong link between soil type and vegetational development must be considered when applying pollen and plant macrofossil data for temperature reconstructions.

- The concentration of Bromme Culture finds within the region dominated by birch woods indicates that its restricted distribution is linked to an adaptation to the variable regional environment which offered the opportunity for exploitation of diverse resources.

Acknowledgments The authors would like to thank two anonymous reviewers for valuable comments on an earlier version of this manuscript. Peter Friis Møller (GEUS) is thanked for allowing us to use unpublished radiocarbon dates of tree birch megafossils from Birkerød. We would also like to thank Catherine Jessen for translating the manuscript. MFM would personally like to thank Hilary Birks for her support and inspiration over the years of the Slotseng project. The preparation of this manuscript was carried out under the auspices of the National Museum of Denmark as part of the research initiative Northern Worlds and a collective project grant awarded to Charlie Christensen by the Danish Council for Independent Research I Humanities (FKK Ref. no. 273-08-0424).

Open Access This article is distributed under the terms of the Creative Commons Attribution License which permits any use, distribution, and reproduction in any medium, provided the original author(s) and the source are credited.

\section{References}

Aaris-Sørensen K (2009) Diversity and dynamics of the mammalian fauna in Denmark throughout the last glacial-interglacial cycle, 115-0 kyr B.P.. Fossils Strata 57:1-59

Aaris-Sørensen K, Liljengren R (2004) Late Pleistocene remains of giant deer (Megaloceros gigantues Blumenbach) in Scandinavia: chronology and environment. Boreas 33:61-73

Aarnes I, Kühl N, Birks HH (2012) Quantitative climate reconstruction from late-glacial and early Holocene plant macrofossils in western Norway using the probability density function approach. Rev Palaeobot Palynol 170:27-39

Andersen STH (1980) Early and Late Weichselian chronology and birch assemblages in Denmark. Boreas 9:53-69

Aslyng HC (1976) Klima, jord og planter. Kulturteknik I 5. udgave. Den Kgl. Veterinær-og Landbohøjskole. DSR Forlaget, København

Aura JE, Carrión Y, Estrelles E, Jordà GP (2005) Plant economy of hunter-gatherer groups at the end of the last Ice Age: plant macroremains from the cave of Santa Maira (Alacant, Spain) ca. 12,000-9,000 в.P. Veget Hist Archaeobot 14:542-550

Bennike O, Jensen JB (1998) Late- and post-glacial shore level changes in the southwestern Baltic Sea. Bull Geol Soc Denmark 45:27-38

Bennike O, Jensen JB (2013) A Baltic Ice Lake lowstand of latest Allerød age in the Arkona Basin, southern Baltic Sea. Geol Surv Denmark Greenland Bull 28:17-20

Bennike O, Jensen JB, Lemke W, Kuijpers A, Lomholt S (2004a) Late- and postglacial history of the Great Belt, Denmark. Boreas 33:18-33

Bennike O, Sarmaja-Korjonen K, Seppänen A (2004b) Reinvestigation of the classic late-glacial Bølling Sø sequence, Denmark: chronology, macrofossil, Cladocera and chydorid ephippia. J Quat Sci 19:465-478

Birks HJB (1968) The identification of Betula nana pollen. New Phytol 67:309-314

Birks HH (1993) The importance of plant macrofossils in late-glacial climatic reconstructions: an example from Western Norway. Quat Sci Rev 12:719-726

Birks HH (2001) Plant macrofossils. In: Smol JP, Birks HJB, Last WM (eds) Tracking environmental change using lake sediments, vol 3: Terrestrial, algal, and siliceous Indicators. (Developments in Paleoenvironmental Research 3). Kluwer, Dordrecht, pp 49-74

Birks HH (2003) The importance of plant macrofossil in the reconstruction of late glacial vegetation and climate: examples from Scotland, western Norway, and Minnesota, USA. Quat Sci Rev 22:453-473

Birks HH, Birks HJB (2000) Future uses of pollen analysis must include plant macrofossils. J Biogeogr 27:31-35 
Birks HH, Birks HJB (2006) Multi-proxy studies in palaeolimnology. Veget Hist Archaeobot 15:235-251

Bos JAA, Bohncke SJP, Janssen CR (2006) Lake-level fluctuations and small-scale vegetation patterns during the late glacial in The Netherlands. J Paleolimnol 35:211-238

Bos JAA, Verbruggen F, Engels S, Crombé P (2012) The influence of environmental changes on local and regional vegetation patterns at Rieme (NW Belgium): implications for Final Palaeolithic habitation. Veget Hist Archaeobot 22:17-38

Brandt I (1954) Late-glacial macroscopic plant remains from Bøllings $\varnothing$. Danmarks Geologiske Undersøgelse, II. Række $80: 156-158$

Brauer A, Litt T, Negendank JFW, Zolitschka B (2001) Lateglacial varve chronology and biostratigraphy of lakes Holzmaar and Meerfelder Maar, Germany. Boreas 30:83-88

Bronk Ramsey C (2009) Bayesian analysis of radiocarbon dates. Radiocarbon 51:337-360

Coope GR, Lemdahl G, Lowe JJ, Walking A (1998) Temperature gradients in northern Europe during the last glacial-Holocene transition (14-9 14C kyr B.P.) interpreted from coleopteran assemblages. J Quat Sci 13:419-433

De Klerk P (2008) Patterns in vegetation and sedimentation during the Weichselian Late-glacial in north-eastern Germany. J Biogeogr 35:1,308-1,322

De Klerk P, Helbig H, Helms S, Janke W, Krügel K, Kühn P, Michaelis D, Stolze S (2001) The Reinberg researches: palaeoecological and geomorphological studies of a kettle hole in Vorpommern (NE-Germany), with special emphasis on a local vegetation during the Weichselian Pleniglacial/Lateglacial transition. Greifswalder Geogr Arb 23:43-131

Eriksen BV (1999) Late Palaeolithic settlement in Denmark-how do we read the record. Folia Quaternaria 70:157-173

Fischer A, Mortensen BN (1977) Trollesgavebopladsen. Et eksempel på anvendelsen af EDB inden for arkæologien. Nationalmuseets Arbejdsmark 1977:90-95

Fischer A, Mortensen MF, Henriksen PS, Rørbeck D, Olsen J (2013a) Dating the Trollesgave site and the Bromme culture-chronological fix-points for the Lateglacial settlement of southern Scandinavia. J Archaeol Sci 40:4663-4674

Fischer A, Clemmensen LB, Donahue R, Heinemeier J, LykkeAndersen H, Lysdahl P, Mortensen MF, Olsen J, Petersen PV (2013b) Late Palaeolithic Nørre Lyngby - a northern outpost close to the west coast of Europe. Quartär 60:137-162

Frederiksen P, Rømer JR, Münier B (2009) Arealdækning i Danmark fra omkring 1800-2000. In: Odgaard BV, Rømer JR (eds) Dansk landbrugs landskaber gennem 2000 år-fra digevoldninger til støtteordninger. Aarhus Universitetsforlag, Aarhus N, pp 59-80

Gramsch B, Beran J, Hanik S, Sommer RS (2013) A Palaeolithic fishhook made of ivory and the earliest fishhook tradition in Europe. J Archaeol Sci 40:2,458-2,463

Hartz N, Milthers V (1901) Det senglaciale ler i Allerød Teglværksgrav. Meddelelser fra Dansk Geologisk Forening. København $8: 31-60$

Hicks S (2001) The use of annual arboreal pollen deposition deposition values for delimiting tree-lines in the landscape and exploring models of dispersal. Rev Palaeobot Palynol 117:1-29

Hoek WZ (1997) Late-glacial and early Holocene climatic events and chronology of vegetation development in the Netherlands. Veget Hist Archaeobot 6:197-213

Hoek WZ (2001) Vegetation response to the $\sim 14.7$ and $\sim 11.5 \mathrm{ka}$ cal. B.P. climate transitions: is vegetation lagging climate? Glob Planet Chang 30:103-115

Hofstetter S, Tinner W, Valsecchi V, Carraro G, Conedera M (2006) Lateglacial and Holocene vegetation history in the Insubrian Southern Alps-new indications from a small-scale site. Veget Hist Archaeobot 15:87-98
Houmark-Nielsen M, Kjær KH (2003) Southwest Scandinavia, 40-15 kyr B.P.: palaeogeography and environmental change. J Quat Sci 18:769-786

Iversen J (1942) En pollenanalytisk Tidsfæstelse af Freskvandslagene ved Nørre Lyngby, vol 10. Meddelelser fra Dansk Geologisk Forening, København, pp 130-151

Iversen J (1947) Plantevækst, dyreliv og klima I det senglaciale Danmark. Geol Fören Stockh Förh 69:67-78

Iversen J (1954) The late-glacial flora of Denmark and its relation to climate and soil. Danmarks Geologiske Undersøgelse. II. Række 80:87-119

Jensen J (2001) Danmarks Oldtid, Stenalderen 13,000-2,000 f. Kr, 1st edn. Gyldendal, København

Johansson AD (2003) Stoksbjerg Vest. Et senpalæolitisk fundkompleks ved Porsmose, Sydsjælland. Fra Bromme-til Ahrensburgkultur i Norden. Nordiske Fortidsminder serie C3. Det Kongelige Nordiske Oldskriftselskab, København

Jönsson BL (1988) The late Weichselian macrofossil flora at Kullaberg, S Sweden, and its palaeoenvironmental implications. Lundqua Thesis 24:87-119

Kolstrup E (1982) Late-glacial pollen diagrams from Hjelm and Draved Mose (Denmark) with a suggestion of the possibility of drought during the earlier Dryas. Rev Palaeobot Palynol 36:35-63

Kolstrup E (2007) Lateglacial older and younger coversand in northwest Europe: chronology and relation to climate and vegetation. Boreas 36:36-75

Krog H (1954) Pollen analytical investigation of a ${ }^{14} \mathrm{C}$-dated Allerød section from Ruds Vedby. Danmarks Geologiske Undersøgelse. II. Række 80:120-139

Lohne ØS, Mangerud J, Birks HH (2013) Precise ${ }^{14} \mathrm{C}$ ages of the Vedde and Saksunarvatn ashes and the Younger Dryas boundaries from western Norway and their comparison with the Greenland Ice Core (GICC05) chronology. J Quat Sci 28:490-500

Mathiassen T (1947) En palæolitisk boplads ved Bromme. Fra Nationalmuseets Arbejdsmark 1947:5-10

Mortensen MF, Birks HH, Christensen C, Holm J, Noe-Nygaard N, Odgaard BV, Olsen J, Rasmussen KL (2011) Late-glacial vegetation development in Denmark-new evidence based on macrofossils and pollen from Slotseng, a small-scale site in southern Jutland. Quat Sci Rev 30:2,534-3,550

Mortensen MF, Henriksen PS, Christensen C, Olsen J (in press). Vegetation development in southeast Denmark during the Weichselian late glacial—preliminary resoults from the Hassel $\varnothing$ basin. Northern Worlds conference paper

Mossberg B, Stenberg L (2003) Den nye nordiske flora. Gyldendalske Boghandel, Nordisk Forlag A/S, Copenhagen

Münier B (2009) Naturgeografi i undersøgelsesområderne. In: Odgaard B, Rømer JR (eds) Dansk landbrugs landskaber gennem 2000 år-fra digevoldninger til støtteordninger. Aarhus Universitetsforlag, Aarhus, pp 23-40

Nadel D, Danin A, Power RC, Rosen AM, Bocquentin F, Tsatskin A, Rosenberg D, Yeshurun R, Weissbrod L, Rebollo NR, Barzilai O, Boaretto E (2013) Earliest floral grave lining from 13,700 to 11,700-year-old Natufian burials at Raqefet Cave, Mt. Carmel, Israel. doi:10.1073/pnas.1302277110. Accessed 1 July 2013

Nathorst AG (1871) Om naagra arktiska vextlämningar i en sötvattenslera vid Alnarp i Skaane. Lunds Universitets Tidsskrift $7: 1-14$

Neugebauer I, Brauer A, Dräger N, Dulski P, Wulf S, Plessem B, Mingram J, Herzschuh U, Brande A (2012) A younger Dryas varve chronology from the Rehwiese palaeolake record in NEGermany. Quat Sci Rev 36:91-102

Nikolov N, Helmisaari H (1992) Silvics of the circumpolar boreal forest trees. In: Shugart HH, Leemans R, Bonan GB (eds) A 
systems analysis of the global boreal forest. Cambridge University Press, Cambridge, pp 13-84

Noe-Nygaard N, Heiberg EO (2001) Late Weichselian lake-level changes in Lake Tøvelde, Møn, Denmark-climate and/or base level forcing. Palaeogeogr Palaeoclim Palaeoecol 174:351-382

Noe-Nygaard N, Knudsen KL, Houmark-Nielsen M (2006) Fra istid til og med Jægerstenalder. In: Larsen G (ed) Naturen i Danmark: geologien, 1st edn. Gyldendal, Copenhagen

Odgaard B (1994) The Holocene vegetation development history of northern West Jutland, Denmark. Opera Bot 123:1-171

Odgaard B, Nielsen AB (2009) Udvikling I arealdækning I perioden 0-1850. Pollen og landskabshistorie. In: Odgaard B, Rømer JR (eds) Dansk landbrugs landskaber gennem 2000 år-fra digevoldninger til støtteordninger. Aarhus Universitetsforlag, Aarhus, pp 41-58

Packham JR, Harding DJL, Hilton GM, Stuttard RA (1996) Functional ecology of woodlands and forests. Chapman and Hall, London

Paus A (1995) The Late Weichselian and early Holocene history of tree birch in south Norway and the Bølling Betula time-lag in northwest Europe. Rev Palaeobot Palynol 85:243-262

Pedersen KB (2009) Stederne og menneskene-Istidsjægere omkring Kundshoved Odde. Forlaget Museerne.dk, Odense

Pedersen KB, Petersen EB (2006) Variability in the Late Palaeolithic: the example of Stoksbjerg Bro, Zealand, Denmark. In: Hansen KM, Pedersen KB (eds) Across the western Baltic. (Sydsjællands Museums Publikationer 1). Sydsjællands Museum, Vordingborg, pp 75-92

Petersen EB (2009) The settling of early Man in Southern Scandinavia $12,500-8,700$ cal B.C.. In: Street M, Barton N, Terberger T (eds) Humans, environment and chronology of the Late Glacial of the North European Plain. RGZM Tagungen 6. RGZM, Mainz, pp 89-130

Petersen PM, Vestergaard P (2006) Vegetationsøkologi. Gyldendalske Boghandel, Nordisk Forlag A/S, Copenhagen, pp 1-189

Rasmussen SO, Andersen KK, Svensson AM, Steffesen JP, Vinter BM, Clausen HB, Siggaard-Andersen ML, Johnsen SJ, Larsen LB, Dahl-Jensen D, Bigler M, Röthlisberger R, Fischer H, GotoAzumz K, Hansson ME, Ruth U (2006) A new Greenland ice core chronology for the Late Glacial and Early Holocene. J Geophys Res 111:D06102. doi:10.1029/2005JD006079

Reimer PJ, Baillie MGL, Bard E, Bayliss A, Beck JW, Blackwell PG, Ramsey CB, Buck CE, Burr GS, Edwards RL, Friedrich M, Grootes PM, Guilderson TP, Hajdas I, Heaton TJ, Hogg AG, Hughen KA, Kaiser KF, Kromer B, McCormac FG, Manning SW, Reimer RW, Richards DA, Southon JR, Talamo S, Turney CSM, Van der Plicht J, Weyhenmeye CE (2009). Intcal09 and Marine09 Radiocarbon age calibration curves, 0-50,000 years cal B.P. Radiocarbon 51:1,111-1,150

Renssen H, Isarin RFB (2001) The two major warming phases of the last deglaciation at $\sim 14.7$ and $\sim 11.5 \mathrm{ka}$ cal. B.P. in Europe: climate reconstructions and AGCM experiments. Glob Planet Chang 30:117-153

Revedin A, Aranguren B, Becattini R, Longo L, Marconi E, Lippi MM, Skakun N, Sinitsyn A, Spiridonova E, Svoboda J (2010)
Thirty thousand-year-old evidence of plant food processing. Proc Nat Acad Sci USA 107:18,815-18,819

Riede F (2008) The Laacher See-eruption (12,920 B.P.) and material culture change at the end of the Allerød in Northern Europe. J Archaeol Sci 35:591-599

Riede F (2012) A possible Brommian shaft-smoother from the site of Møllehøje, north-western Denmark. Mesolithic Miscellany 22:10-18

Riede F, Edinborough K (2012) Bayesian radiocarbon models for the cultural transition during the Allerød in southern Scandinavia. J Archaeol Sci 39:744-756

Seppä H, Hicks S (2006) Integration of modern and past pollen accumulation rate (PAR) records across the arctic tree-line: a method for more precise vegetation reconstructions. Quat Sci Rev 25:1,501-1,516

Seppä H, Birks HH, Birks HJB, Odland A, Poska A, Veski S (2004) A modern pollen-climate calibration set from northern Europe: developing and testing a tool for palaeoclimatological reconstructions. J Biogeogr 31:251-267

Sørensen L (2010) The Laacher See volcanic eruption-Challenging the idea of cultural disruption. Acta Archaeol 81:270-281

Stockmarr J (1975) Biostratigraphic studies in Late Weichselian sediments near Bøllingsø. Danmarks Geologiske Undersøgelse, Årbog 1974:71-89

Terberger (2006) From the first humans to the Mesolithic hunters in the northern German lowlands-current results and trends. In: Hansen KM, Pedersen KB (eds) Across the western Baltic 23-56. Sydsjællands Museum, Vordingborg

Theuerkauf M, Joosten H (2009) Substrate dependency of Lateglacial forests in north-east Germany: untangling vegetation patterns, ecological amplitudes and pollen dispersal in the past by downscaling regional pollen. J Biogeogr 36:942-953

Theuerkauf M, Joosten H (2012) Younger Dryas cold stage vegetation patterns of central Europe-climate, soil and relief controls. Boreas 41:391-407

Tyldesley JA, Bahn PG (1983) Use of plants in the European palaeolithic: a review of the evidence. Quat Sci Rev 2:53-81

Usinger H (1977) Bölling-Interstadial and Laacher Bimstoff in einem neuen Spätglazial-Profil aus dem Vallensgård Mose/Bornholm. Mit pollengrößenstatistischer Trennung der Birken. Danmarks Geologiske Undersøgelse, Årbog 1977:5-29

Usinger H (1985) Pollenstratigraphischer, vegetations- und klimageschichtliche Gliederung des "Bølling-Allerød Komplexes" in Schleswig-Holstein und ihre Bedeutung für die Spätglazial-Stratigraphie in benachbarten Gebieten. Flora 177:1-43

Usinger H (1998) Pollenanalytische Datierung spätpaläolitischer Fundschichten bei Ahrenshöft, Kr. Nordfriesland. Archäologische Nachrichten aus Schleswig-Holstein. Mitteil Archäol Ges Schleswig-Holstein u. Archäol LA Schleswig-Holstein 8:50-73

Van Dinter M, Birks HH (1996) Distinguishing fossil Betula nana and $B$. pubescens using their wingless fruits: implications for the late-glacial vegetational history of western Norway. Veget Hist Archaeobot 5:229-240

Zolitschka B, Brauer A, Negendank JFW et al (2000) Anually dated late Weichselian continental paleoclimate record from the Eifel, Germany. Geology 28:783-786 